\title{
Implementasi nilai-nilai Pancasila melalui budaya sekolah di era digital
}

\author{
Dwi Anggi Wulandaria,1* \\ a SMA Negeri 3 Talang Ubi, PALI, Sumatera Selatan \\ ${ }^{1}$ dwianggiwulandari@gmail.com; \\ *korespondensi penulis
}

\begin{abstract}
ABSTRAK
Tujuan penelitian ini untuk mengetahui bagaimana budaya sekolah dalam mengimplementasikan nilai-nilai pancasila di era kewarganegaraan digital. Teknik pengumpulan data yang digunakan adalah penelitian kepustakaan. Sumber data di dapat dari dokumen yang sesuai dengan variabel berupa surat kabar, buku, prasasti, majalah, agenda dan sebagainya selanjutnya data yang didapat dianalisis dan digeneralisasikan dengan menggunakan kajian teori yang relevan. Hasil penelitian kewarganegaraan digital sebagai praktik dalam berprilaku saling menghormati dan toleran terhadap orang lain dengan meningkatkan pengawasan dari masyarakat. Hal tersebut sesuai dengan nilai-nilai yang ada dalam Pancasila yaitu nilai ketuhanan, nilai kemanusiaan, nilai persatuan, nilai kerakyatan, dan nilai keadilan yang dituangkan kedalam budaya sekolah.
\end{abstract}

Kata kunci: budaya sekolah; nilai-nilai pancasila; kewarganegaraan digital

\begin{abstract}
The purpose of this study is to study how school culture applies the values of Pancasila in the era of digital citizenship. The data collection technique used is library research. Sources of data can be obtained from documents that correspond to variables consisting of newspapers, books, inscriptions, magazines, agendas and further data obtained and generalized using relevant theoretical studies. The results of digital citizenship research as practices in behaving mutually respectful and tolerant of others by increasing surveillance from the community. This is in accordance with the values contained in Pancasila, namely the value of God, the value of assessment, the value of unity, the value of society, and the value of justice as outlined in the school culture.
\end{abstract}

Keywords: school culture, implementation, Pancasila values, digital citizenship

Copyright (C2018Universitas Ahmad Dahlan, All Right Reserved

\section{PENDAHULUAN}

Indonesia merupakan negara majemuk yang kaya akan budaya, suku, ras, bahasa, dan agama. Perbedaan yang ada tidak membuat kesatuan bangsa menjadi terpecahbela. Bhineka Tunggal Ika menjadi semboyan untuk mengingatkan bahwa negara Indonesia memiliki sikap toleransi atas perbedaan yang ada. Nilai-nilai Pancasila terkandung dalam setiap aktivitas masyarakat Indonesia baik dari sila pertama, sila kedua, sila ketiga, sila keempat, dan sila kelima. Setiap sila dalam Pancasila memiliki nilai atau makna yang sangat mendalam dan dapat kita temukan dalam kehidupan sehari-hari tanpa kita sadari. Nilai-nilai Pancasila telah melekat pada diri masing-masing individu. Tercermin dalam budaya yang ada pada masyarakat. Budaya dapat kita lihat pada perilaku, sikap dan cara untuk beradabtasi dengan lingkungan. Penanaman nilai-nilai Pancasila sangat diperlukan guna membentuk pribadi individu masyarakat Indonesia. Kemajuan suatu bangsa akan ditentukan oleh pribadi individu yang memiliki keperibadian baik.

Pancasila merupakan pandangan hidup bangsa Indonesia yang memiliki makna bahwa semua perbuatan, tindakan, serta tingkah laku setiap warga negaranya harus menjiwai dan mencerminkan seluruh sila Pancasila. Lima nilai yang terdapat dalam Pancasila yaitu nilai ketuhanan yakni meyakini adanya tuhan dengan mengerjakan perintah-Nya dan menjauhi larangan-Nya, nilai kemanusiaan yakni pengakuan bahwa adanya martabat yang dimiliki oleh manusia, nilai persatuan merupakan adanya persatuan bangsa masyarakat yang berada di wilayah Indonesia, nilai kerakyatan bahwa kedaulatan berada ditangan rakyat, dan nilai keadilan merupakan wujud keadilan sosial yang ada dalam kehidupan seluruh rakyat Indonesia (Rahmani \& Suwanda, 2014). 
Implementasi nilai-nilai Pancasila dapat kita jumpai dalam kehidupan sehari-hari baik dalam lingkungan keluarga, sekolah, dan masyarakat. Khusus di dalam dunia pendidikan nilai-nilai Pancasila banyak di terapkan di lingkungan sekolah. Sekolah merupakan tempat belajar dan mengajar bagi peserta didik. Menurut Kompri (2015, hal. 28) sekolah merupakan organisasi yang dirancang untuk memberikan kontribusi peningkatan kualitas hidup masyarakat serta mampu mendidik peserta didik secara optimal. Peran sekolah selain untuk mempersiapkan peserta didik di dalam kehidupannya, sekolah merupakan cerminan dari kehidupan masyarakat yang tidak terlepas dari kenyataan-kenyataan di dalam masyarakat, sebagai evaluator kondisi masyarakat, dan sebagai lingkungan pengganti keluarga dan pendidik. Setiap sekolah memiliki aturannya dan budaya sekolah masing-masing dalam melaksanakan tugas belajar dan mengajar.

Budaya sekolah merupakan nilai-nilai, kepercayaan, dan tindakan sebagai hasil dari keputusan dan kesepakatan bersama yang dituangkan menjadi komitmen seluruh anggota untuk dilaksanakan dengan konsisten dan konsekuen. Budaya sekolah identik sebagai ciri khas atau karakteristik sekolah melalui nilai, sikap, kebiasaan, dan tindakan yang ditunjukan oleh seluruh warga sekolah yang membentuk kesatuan dari sistem sekolah (Komariah \& Triatna, 2016, hal. 102). Budaya sekolah secara tidak langsung membatu menerapakan nilai-nilai yang terkandung dalam Pancasila pada saat ini dimana teknologi semakin berkembang.

Pengaruh globalisasi saat ini telah memberikan banyak warna pada kehidupan masyarakat dengan adanya kemajuan teknologi. Kemajuan teknologi tidak dapat dipisahkan dalam budaya dan peradaban manusia. Kemajuan teknologi memberikan dampak negatif dan positif. Dampak negatif berupa perilaku manusia yang menyimpang dari nilai-nilai, norma, dan moral. Perlunya pengarahan kepada peserta didik akan kewarganegaraan digital. Kewarganegaraan digital untuk memperluas pemahaman tentang pentingnya kewarganegaraan global yang efektif berupa akses yang adil, kesadaran global, pemahaman budaya, dan penggunaan teknologi yang aman, sehat, legal, etis dan bertanggung jawab kedalam dasar-dasar permodelan dan mengintegrasikan teknologi ke dalam kurikulum (Armfield \& Blocher, 2019). Guru memiliki peran penting dalam menjelaskan peranan kewarganegaraan digital pada peserta didik agar tidak menyalah gunakan kemajuan teknologi. Menurut Mulyasa (2008), guru merupakan komponen yang berpengaruh terhadap proses serta hasil pendidikan yang berkualitas.
Dalam artikel ini penulis menjelaskan budaya sekolah dalam mengimplementasikan nilai-nilai pancasila di era kewarganegaraan digital. Artikel ini ditulis dengan berbagai literasi sebagai acuan dan bahan pustaka.

\section{METODE}

Metode yang digunakan dalam artikel ini menggunakan jenis penelitian library research (penelitian kepustakaan). Sumber data di dapat dari dokumen yang sesuai dengan variabel berupa surat kabar, buku, prasasti, majalah, agenda dan sebagainya selanjutnya data yang didapat dianalisis dan digeneralisasikan dengan menggunakan kajian teori yang relevan (Mahmud, 2011).

\section{HASIL DAN PEMBAHASAN}

Budaya sekolah bersifat dinamis dimana nilai-nilai, prinsip-prinsip, tradisi serta kebiasaankebiasaan yang ada dalam kondisi sekolah merupakan gabungan dari seluruh warga sekolah yang memiliki latar belakang kehidupan sosial yang berbeda serta berinteraksi secara berkelanjutan dengan membentuk sistem nilai yang menjadi milik bersama di sekolah. Menurut Zamroni (2013), pentingnya sekolah mempunyai budaya. Sekolah sebagai suatu organisasi harus memiliki: 1) kemampuan untuk hidup, beradaptasi, tumbuh berkembang dengan berbagai lingkungan yang ada dan 2) integrasi internal yang memungkinkan sekolah untuk menghasilkan individu yang memiliki sifat positif. Budaya sekolah harus memiliki pola asumsi dasar yang mendalam, kebiasaan, sejarah sekolah, dan cara dalam menyelesaikan masalah di sekolah.

Budaya sekolah mencerminkan sikap dan perilaku yang berkembang di lingkungan sekolah serta berfungsi dalam membangun karakter atau pribadi peserta didik di era kewarganegaraan digital tanpa melupakan nilai-nilai Pancasila. Menurut Sudrajat (2011), terdapat tiga budaya yang perlu dikembangkan di sekolah yaitu kultur akademik, kultur sosial budaya, dan kultur demokratis yang menjadi prioritas dalam lingkungan sekolah. Pertama, kultur akademik memiliki ciri pada setiap keputusan dan kebijakan didukung atas dasar akademik yang kuat merujuk pada teori dan dasar hukum yang teruji. Warga sekolah selalu menggunakan teori dalam berpikit bertindak serta bersikap dalam aktivitas sehari-hari dengan memiliki ciri-ciri bersifat kritis, analitis, kreatif, objektif, terbuka dalam menerima kritik, disiplin waktu, dinamis, dan berorientasi pada masa depan. Kedua, kultur sosial budaya ada pada pengembangan sekolah dalam memelihara, dan 
mengembangkan budaya yang positif dalam membangun serta menerapkan kehidupan sosial yang harmonis antar warga sekolah. Sekolah menjadi benteng pertahanan dari arus globalisasi serta serangan budaya asing seperti budaya hedonisme, materialisme, dan individualisme. Kultur sosial merupakan suatu sikap manusia dalam berinteraksi satu dengan lainnya dalam kelompok. Sedangkan kultur budaya merupakan gabungan yang kompleks dari pengetahuan, seni, hukum, kepercayaan, moral, adat serta kebiasaan yang ada dari turun temurun. Ketiga, kultur demokratis yang menampilkan kehidupan yang mengakomodasi perbedaan untuk bersama membangun kemajuan bangsa. Kultur demokratis tercermin dalam mengambil dan menghargai keputusan warga sekolah serta mengetahui hak dan kewajiban masing-masing baik diri sendiri, bangsa dan negara.

Budaya sekolah yang ada menjadi pondasi bagi peserta didik dan warga sekolah dalam pembentukan karakter. Berdasarkan Permendikbud Nomor 20 Tahun 2018 Tentang Penguatan Pendidikan Karakter Pada Satuan Pendidikan Formal, PPK dilaksanakan dengan menerapkan nilai-nilai Pancasila dalam pendidikan karakter. Nilai-nilai yang dimaksud merupakan perwujudan dari lima nilai utama yang saling berkaitan yaitu religiusitas, nasionalisme, kemandirian, gotong royong, dan integritas yang terintegrasi dalam kurikulum. Selanjutnya penyelenggaraan PPK yang mengoptimalkan fungsi kemitraan tripusat pendidikan (sekolah, keluarga, dan masyarakat) dilaksanakan dengan pendekatan berbasis kelas, budaya sekolah, dan masyarakat.

Pancasila tidak hanya mengandung nilai-nilai budaya bangsa akan tetapi sumber hukum dasar nasional, dan merupakan perwujudan dari cita-cita dalam semua aspek kehidupan nasional. Nilainilai Pancasila terdapat dalam pendidikan karakter yang ada pada budaya sekolah. Budaya sekolah secara tidak langsung telah mengimplementasikan nilai-nilai Pancasila dalam pendidikan karakter di sekolah. Menurut Asrori (2016), mengintegrasikan nilai Pancasila dalam sekolah berbasis budaya dapat mengasumsikan pendekatan fenomenologis dalam konteks peserta didik sebagai wadah dengan potensinya dan perlu diisi materi agar peserta didik tidak gagal. Perkembangan zaman khususnya dalam bidang teknologi memberikan dampak positif serta negatif pada masyarakat negara di dunia. Meminimalisir dampak negatif yang akan ditimbulkan dari hal tersebut perlunya pengetahuan tentang kewarganegaraan digital bagi peserta didik. Kewarganegaraan digital berawal dari adanya keprihatinan yang telah ada sejak lama terhadap etika dalam menggunakan komputer atau dampak sosial dari teknologi komputer (Moor, 1985).

Menurut Ribble (2015), kewarganegaraan digital merupakan panduan yang dimediasi untuk mengarahkan tindakan atau perilaku manusia sehingga semua dapat mengambil manfaat dalam masyarakat digital. Selanjutnya menurut Ohler (Ohler, 2012), kewarganegaraan digital merupakan pendidikan karakter di era digital. Kewarganegaraan digital sebagai praktik dalam berprilaku saling menghormati dan toleran terhadap orang lain dengan meningkatkan pengawasan dari masyarakat sipil lainnya (Jones \& Mitchell, 2016). Kategori kewarganegaraan digital dengan mengatur tiga dimensi yaitu menghormati diri sendiri dan orang lain, mendidik diri sendiri saat terhubung dengan orang lain, dan melindungi diri sendiri dan orang lain (Ribble \& Miller, 2013). Berdasarkan hal tersebut dapat kita ketahui bahwa kewarganegaraan digital penting untuk di terapkan dalam pendidikan di sekolah guna mengurangi dampak negatif dari kemajuan teknologi. Budaya sekolah menjadi pondasi dasar untuk membentuk karakter peserta didik berdasarkan nilai-nilai pancasila dan pembelajaran mengenai kewarganegaraan digital.

\section{KESIMPULAN}

Kecanggihan teknologi pada era globalisasi tidak dapat dihindari dari dampak positif dan negatif. Dampak negatif dari penggunaan teknologi pada saat ini dapat diminimalisir dengan adaya pendidikan kewarganegaraan digital yang dapat diterapkan di sekolah yang secara tidak langsung diimplementasikan dalam budaya sekolah tanpa meninggalkan nilai-nilai Pancasila yang luhur. Kewarganegaraan digital merupakan pendidikan karakter di era digital (Ohler, 2012). Pendidikan karakter di era digital dilaksanakan dengan menerapkan nilai-nilai Pancasila. Nilainilai yang dimaksud merupakan perwujudan dari lima nilai utama yang saling berkaitan yaitu religiusitas, nasionalisme, kemandirian, gotong royong, dan integritas berdasarkan Permendikbud Nomor 20 Tahun 2018 Tentang Penguatan Pendidikan Karakter Pada Satuan Pendidikan Formal. Kewarganegaraan digital sebagai praktik dalam berprilaku saling menghormati dan toleran terhadap orang lain dengan meningkatkan pengawasan dari masyarakat sipil lainnya (Jones dan Mitchell, 2015). Hal tersebut sesuai dengan nilai-nilai yang ada dalam Pancasila yaitu nilai ketuhanan, nilai kemanusiaan, nilai persatuan, nilai kerakyatan, dan nilai keadilan yang dituangkan kedalam budaya sekolah. 


\section{UCAPAN TERIMA KASIH}

Terimakasih penulis sampaikan kepada pihak-pihak yang dengan sabar memberikan bimbingan, masukan, arahan serta dukungan kepada penulis dalam menyusun artikel ini dan telah memberi dukungan untuk penerbitan artikel.

\section{DAFTAR PUSTAKA}

Armfield, S. W. J., \& Blocher, J. M. (2019). Global Digital Citizenship: Providing Context. TechTrends, 63, 470-476. https://www.deepdyve.com/lp/springer_jo urnal/global-digital-citizenship-providingcontext-t9uypkfl7V

Asrori, M. A. R. (2016). Integrasi nilai-nilai Pancasila dalam pendidikan karakter dan budaya bangsa yang berbasis pada lingkungan sekolah. Jurnal Rontal Keilmuan PPKn, 2(1), 1-11.

Jones, L. M., \& Mitchell, K. J. (2016). Defining and measuring youth digital citizenship. New Media \& Society, 18(9). https://doi.org/10.1177/146144481557779 7

Komariah, A., \& Triatna, C. (2016). Visionary leadership : menuju sekolah efektif. Bumi Aksara.

Kompri. (2015). Manajemen Pendidikan: KomponenKomponen Elementer Kemajuan Sekolah. ArRuzz Media.

Mahmud. (2011). Metode penelitian pendidikan. Pustaka Setia.
Moor, J. H. (1985). What is computer ethics? Metaphilosophy, 16(4), 266-275. https://doi.org/10.1111/j.14679973.1985.tb00173.x

Mulyasa, E. (2008). Standar Kompetensi dan Sertifikasi Guru. Remaja Rosdakarya.

Ohler, J. (2012). Digital Citizenship Means Character Education for the Digital Age. Kappa Delta Pi Record, 47(sup1), 25-27. https://doi.org/10.1080/00228958.2011.10 516720

Rahmani, A., \& Suwanda, I. M. (2014). Strategi sekolah dalam menanamkan nilai-nilai Pancasila pada siswa di SDN Bubutan IV Kota Surabaya. Kajian Moral dan Kewarganegaraan, 3(2), 1111-1126.

Ribble, M. (2015). Digital Citizenship in Schools: Nine Elements All Students Should Know (3 ed.). International Society for Technology in Education.

Ribble, M., \& Miller, T. N. (2013). Educational leadership in an online world: Connecting students to technology responsibly, safely, and ethically. Journal of Asynchronous Learning Network, 17(1), 137-145. https://doi.org/10.24059/olj.v17i1.310

Sudrajat, A. (2011). MENGAPA PENDIDIKAN KARAKTER. Jurnal Pendidikan Karakter, 1(1). https://doi.org/10.21831/jpk.v1i1.1316

Zamroni. (2013). Pendidikan demokrasi pada masyarakat multikultural. Ombak. 